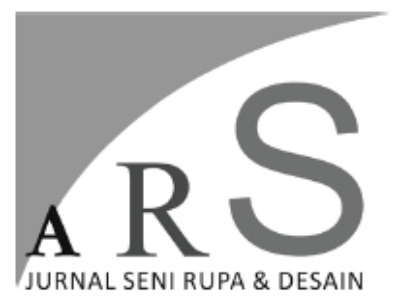

Volume 22 Nomor 3 , Desember 2019

\section{PENGELOLAAN LUKISAN-LUKISAN KOLEKSI MUSEUM ISTANA KEPRESIDENAN YOGYAKARTA}

\author{
Khoirul Anam \\ Program Studi Tata Kelola Seni \\ Fakultas Seni Rupa Institut Seni Indonesia Yogyakarta
}

\begin{abstract}
ABSTRAK
Penelitian ini bertujuan untuk mengkaji dan memperoleh pemahaman yang benar serta mendalam, tentang pengelolaan lukisan-lukisan koleksi museum. Metode pendekatan yang dipakai dalam penelitian ini adalah deskriptif. Adapun pengumpulan data dilakukan dengan pengamatan dan pendokumentasian langsung terhadap pengelolaan lukisan-lukisan koleksi, mempelajari dan mencatat data dari berbagai sumber. Penelitian ini menggunakan landasan teori tentang pengelolaan koleksi museum yang meliputi struktur organisasi, pengadaan koleksi, pendataan, penyajian, pengamanan dan pemeliharaan koleksi. Hasil penelitian ini menunjukkan bahwa pengelolaan koleksi museum ini, mempunyai struktur organisasi museum yang tidak seperti organisasi museum yang lain, seperti memiliki kepala museum dan jajarannya, museum hanya memiliki pengelola. Perbedaan ini dinilai menyebabkan kurang optimalnya pengelolaan koleksi. Adapun untuk pengalihan risiko dengan menggunakan asuransi belum dilakukan pengelola, namun di sisi lain secara menyeluruh, pengelolaan koleksi yang meliputi; pengadaan koleksi, pendataan, penyajian, pengamanan dan pemeliharaan koleksi berada dalam taraf baik.
\end{abstract}

Kata Kunci : pengelolaan, lukisan, koleksi, museum, Sukarno, Yogyakarta

\begin{abstract}
This research aims to review and gain a true understanding and depth, about the paintings management of the museum's collection. The approach method used in this research is descriptive. The data collection is done by direct observation and documentation on the management of collection paintings, studying and recording data from various sources. This research uses the theoretical basis of the museum collections management that include organizational structure, collection procurement, data collection, presentation, security and collection maintenance. The results of this research indicate that the management of the collection at the museum, has a museum organizational structure that unlike other museum organizations, such as having the head of museum and his staff, the museum only has a manager. This difference is rated to be less optimal in collection management. As for the transfer of risk by using insurance has not been done by managers, but on the other hand as a whole, collection management that includes; collection procurement, data collection, presentation, security and maintenance of the collection is in good level.
\end{abstract}

Keywords: paintings, collections, Mmanagement, museum, Sukarno, Yogyakarta

\section{Pendahuluan}

Ketika Belanda mencoba kembali untuk menjajah bangsa Indonesia dengan menguasai Jakarta pada 1946, Sukarno mengumumkan pemindahan kedudukan pemerintah ke daerah yang bebas dari gangguan Belanda, yaitu daerah Yogyakarta. Pada 3 Januari 1946, Presiden pertama Ir. 
Sukarno memboyong sang istri Fatmawati, anak pertama Guntur Sukarno, dan orang tua Fatmawati. Ibu Kota Republik Indonesia resmi berpindah dari Jakarta ke Yogyakarta dan menjadi pusat Pemerintahan Indonesia yang belum genap berusia lima bulan pada 4 Januari 1946. (Setiyono, 2017)Ratusan ribu orang ikut mengungsi dari berbagai daerah yang diduduki Belanda ke Yogyakarta, tidak terkecuali para seniman juga ikut bermigrasi pada masa antara 1946 - 1947. (Susanto, 2014:16)

Sejak para seniman bermigrasi ke Yogyakarta, seni dan budaya tumbuh secara signifikan, terutama bidang seni rupa. Pada tahun 1946, para pelukis seperti Affandi, Rusli, Hendra Gunawan, dan Harijadi S. membentuk Sanggar Masyarakat, dan disusul S. Sudjojono bersama Seniman Indonesia Muda (SIM) pada tahun 1948. Affandi dan Hendra Gunawan lalu bergabung dengan SIM, tetapi kebersamaan itu tidak lama karena ada perselisihan pendapat dengan S. Sudjojono. Setelah keluar, keduanya mendirikan Pelukis Rakyat (PR) pada tahun 1947. Keduanya-SIM dan PR-mempunyai pengaruh besar pada perkembangan seni rupa di Yogyakarta (Burhan, 2013:22)

Sukarno juga sering mengundang para pelukis dan seniman untuk berdiskusi seputar masalah kesenian di pendopo belakang Gedung Agung (Istana Kepresidenan Yogyakarta). Setelah itu, lahirlah perguruan tinggi seni rupa Indonesia yang bernama ASRI (Akademi Seni Rupa Indonesia) diresmikan pada 15 Desember 1949. Banyak karya-karya besar yang lahir dari seniman-seniman besar di ASRI dan kota ini. Selain itu, banyak kegiatankegiatan seni yang lahir, seperti; Festival Kesenian Yogyakarta, Biennale Jogja, Artjog, dan kegiatan pameran-pameran seni rupa yang menjamur di galeri-galeri maupun ruang alternatif. Maka dari itu, julukan Yogyakarta sebagai kota seni rasanya suatu hal yang tidak berlebihan.

Sementara itu, melihat aktivitas kesenian yang tumbuh semakin intensif, aktivitas kesenian menghasilkan banyak ilmu pengetahuan, benda seni dan sejarah. Oleh sebab itu, museum sangat dibutuhkan, gedung yang digunakan sebagai tempat untuk pameran, benda-benda yang patut mendapat perhatian umum seperti peninggalan bersejarah, seni dan ilmu pengetahuan atau barang kuno. (Susanto, 2011:268) Museum berperan penting sebagai lembaga yang merawat dan mengelola benda seni untuk menjaga sejarah kesenian dan kebudayaan. Museum menjadi bukti konkret atas kepemilikan kesenian dan kebudayaan melalui arsip dokumen dan arsip benda seni dan benda bersejarah, dimana bangsa lain tidak bisa serta-merta dengan mudah mengklaim ilmu pengetahuan, kesenian dan kebudayaan. Yogyakarta mempunyai banyak sebutan, antara lain sebagai kota pelajar, kota gudeg, kota seni budaya, kota pariwisata dan sebagainya, kota ini juga pantas disebut sebagai kota museum. Pasalnya ada 32 museum yang tercatat sebagai anggota Badan Musyawarah Musea D.I (Daerah Istimewa) Yogyakarta. (Barahmus, 2017) Selain itu, banyak juga museum yang tidak terdaftar sebagai anggota BMM DIY, seperti museum Rumah Garuda yang dikelola secara pribadi dan Museum Istana Kepresidenan Yogyakarta yang dikelola oleh Kementerian Menteri Sekretaris Negara Republik Indonesia.

Topik penelitian ini dilatari oleh dibukanya Museum Istana Kepresidenan oleh Presiden Republik Indonesia Susilo Bambang Yudhoyono (SBY). Selain itu juga. diresmikanya Museum Balai Kirti pada 18 Oktober 2014 yang ada di Istana Kepresidenan Bogor (Kemendikbud.go.id, 2017) dan Museum Istana Kepresidenan Yogyakarta yang akhirnya bisa dinikmati publik pada tahun yang sama. Selain itu, juga diadakannya pameran besar di Galeri Nasional Indonesia yang memamerkan benda-benda seni koleksi Istana Presiden RI, yang belum pernah dipamerkan untuk publik. Istana Kepresidenan mempunyai koleksi benda seni mencapai 15.911 buah. Dari koleksi tersebut, ada 1.900an bingkai lukisan, lebih dari 500 lukisan adalah karya-karya para perupa Indonesia maupun dunia yang telah diletakan di dinding-dinding Istana dan sebagian diletakan di dalam museum-museum Istana Kepresidenan yang berada di Jakarta, Bogor, Cipanas, Yogyakarta, dan Tampaksiring. (Barahmus, 2017)

$\mathrm{Hal}$ yang paling menarik dari Istana Presiden adalah pengelolaan koleksinya. Istana Presiden menjadi museum terbaik yang mempunyai artefak bagi bangsa ini, memuat 
sejarah perjuangan merebut kemerdekaan hingga sejarah perkembangan seni rupa Indonesia berada di Istana Presiden yang tersebar di enam tempat tersebut. Pengkajian mengenai pengelolaan koleksi seni lukis Istana Kepresidenan dinilai sangat penting untuk mengetahui sejauh mana proses pemeliharaan artefak yang mempunyai sejarah penting bangsa ini. Selain itu bertujuan mengetahui pesan-pesan untuk menyebarkan informasi atau nilai kesenian dan kebudayaan dari artefak seni koleksi Istana Kepresidenan kepada publik. Rasa keingintahuan mengenai aspek pengelolaan koleksi seni Museum Istana Kepresidenan menjadi alasan yang mendasar pada penelitian ini.

\section{Rumusan Masalah}

Rumusan masalah yang akan dikemukakan adalah apa sajakah hal-hal yang terkait dengan pengelolaan lukisan-lukisan koleksi Museum

Istana Kepresidenan Republik Indonesia Yogyakarta?

\section{Tujuan Penelitian}

Penelitian ini bertujuan:

a) Pengadaan dan pendataan lukisan-lukisan koleksi museum.

b) Penyajian lukisan-lukisan koleksi museum.

c) Keamanan dan pemeliharaan lukisanlukisan koleksi museum.

\section{Metode Penelitian}

Metode yang dipakai adalah metode penelitian kualitatif yaitu penelitian yang menghasilkan prosedur analisis atau menafsirkan fenomena yang terjadi dan dilakukan dengan jalan melibatkan berbagai metode yang ada, seperti wawancara, pengamatan dan pemanfaatan data-data dokumen (Moeloeng, 2007:5). Metode penelitian tersebut digunakan sebagai suatu usaha dalam menyelesaikan permasalahan yang diajukan pada rumusan masalah.

a) Metode Pendekatan

Metode Pendekatan yang akan dipakai adalah dengan metode pendekatan deskriptif yaitu melakukan analisis hanya sampai pada taraf deskripsi. (Azwar, 2005:6) Melalui data yang dikumpulkan seperti berupa kata-kata, gambar, dan bukan angka- angka. Hal itu disebabkan oleh adanya penerapan metode kualitatif (Moeloeng, 2007:11)

b) Metode Pengumpulan Data

1. Observasi

2. Studi Pustaka

3. Wawancara

4. Dokumentasi

c) Metode Analisis Data

Analisis data adalah tahap yang sangat pokok dalam menyimpulkan hasil suatu penelitian. Menganalisis data merupakan suatu langkah yang sangat kritis dalam suatu penelitian. Peneliti harus memastikan pola analisis mana yang akan digunakan, apakah analisi statistik (bersifat kuantitatif) ataukah analisis non statistik. (S. Suryabrata, 1998:40) Penelitian ini menggunakan data kualitatif yang menghasilkan data deskriptif.

\section{Hasil Penelitian Dan Pembahasan Museum Istana Kepresidenan Yogyakarta}

Di bagian sisi selatan gedung Istana Kepresidenan Yogyakarta pada 4 Juni 1822 didirikan sebuah bangunan sebagai "Societiet de Vereeniging Yogyakarta". Pemerkasa pembangunan adalah Luitenant de Terria dan Sri Sultan Hamengku Buwono IV sebagai pelindung sekaligus penyedia tanahnya.

Pada masa penjajahan Hindia-Belanda gedung ini berfungsi sebagai tempat hiburan seperti musik, opera, pesta minuman, dan tempat bermain billiard bagi kalangan masyarakat sipil maupun Militer Belanda. Masyarakat menyebutnya sebagai "Kamar Bola" atau "Gedung Jenewer". Gedung ini direnovasi, antara lain pada 1864 dan 1915. Di masa kependudukan Jepang gedung ini berganti nama menjadi "Balai Mataram", dan pada 1952 fungsinya beralih sebagai bioskop dan berganti nama menjadi "Gedung Senisono" yang kemudian diperuntukkan sebagai tempat di mana para seniman Yogya melakukan aktifitas keseniannya. Gedung ini kemudian dikenal sebagai Art Gallery Senisono, atau gedung Antara/PWI.

Sesudah diakuisi dan menjadi bagian Istana Kepresidenan Yogyakarta, dan dipugar pada 1995 yang terdiri atas gedung auditorium, ruang sidang kepresidenan serta ruang pamer dan museum. Gedung Senisono yang dulunya 
dipakai sebagai ruang berkesenian. Sekarang menjadi Museum Istana, tempat dimana koleksi-koleksi benda seni peninggalan Presiden RI ditampilkan, mulai dari Presiden Soekarno yang meliputi lukisan, patung, kriya, keramik, maupun berbagai cenderamata kepresidenan. Diresmikan kembali oleh Presiden Susilo Bambang Yudhoyono pada 2014, bersamaan dengan diresmikanya Museum Balai Kirti pada 18 Oktober 2014 yang ada di Istana Kepresidenan Bogor, yang akhirnya bisa dinikmati publik pada tahun yang sama.

Istana Kepresidenan Yogyakarta terletak di pusat keramaian kota, tepatnya di selatan Jalan Ahmad Yani, kini nama jalan dikembalikan seperti sejarahnya yakni Jalan Margo Mulyo. Lokasinya tepat di jantung ibukota Daerah Istimewa Yogyakarta, persis di sudut barat laut Titik Nol Kilometer Yogyakarta. Lokasi Museum Istana Kepresidenan Yogyakarta sangat strategis, karena berada di tengah kota dan berdekatan dengak pusat pariwisata kota Yogyakarta yaitu Malioboro. Dalam hal ini, meskipun sudah dibuka untuk umum dan mempunyai posisi strategis dalam segi lokasi, Museum Istana Kepresidenan Yogyakarta masih tergolong sepi dibandingkan Museum Benteng Vredeburg yang berada persis di depan istana.

Meskipun dibuka untuk umum, pihak museum tidak menargetkan kunjungan yang banyak, hal ini disebabkan museum masih di bawah naungan atau kompleks Istana Kepresidenan Yogyakarta, belum berdiri sendiri seperti Museum Balai Kirti yang berada di Istana Kepresidenan Bogor. Jadi, jika kita mengunjungi Istana Kepresidenan Yogyakarta, maka kunjungan tersebut satu paket dengan kunjungan Museum Istana Kepresidenan Yogyakarta, dan ketika istana sedang ditempati oleh Presiden RI, maka kunjungan akan ditutup dan yang sudah reservasi akan dibatalkan.

Museum Istana Kepresidenan Yogyakarta sendiri termasuk dalam lima jenis museum, yang masing-masing dapat dilihat dari beberapa sudut pandang. Pertama, dapat dilihat dari jenis koleksi museum; Museum Istana Kepresidenan Yogyakarta termasuk dalam jenis museum seni dan sejarah, karena memuat koleksi-koleksi seni dan memuat sejarah Indonesia. Kedua, dari jenis pembiayaan; Museum Istana Kepresidenan Yogyakarta termasuk dalam jenis museum pemerintah pusat, karena dibiayai langsung dari pemerintah pusat. Ketiga, dipandang dari jenis area; Museum Istana Kepresidenan Yogyakarta termasuk jenis museum nasional, karena berlatar belakang milik Istana Negara. Keempat, dilihat dari jenis penonton: Museum Istana Kepresidenan Yogyakarta termasuk dalam kategori museum publik sejak dibuka pada tahun 2014, yang sebelumnya masuk kategori museum khusus (privat). Kelima, dilihat dari penyajian pameran; Museum Istana Kepresidenan Yogyakarta termasuk dalam jenis museum tradisional, karena masih mengadopsi penyajian konvensional, tidak melibatkan penyajian yang interaktif.

\section{Koleksi Lukisan}

Istana Kepresidenan Yogyakarta memiliki koleksi 494 lukisan yang tersebar di Gedung Kompleks Istana. Sejumlah 435 lukisan sudah terdaftar Barang Milik Negara (BMN) dan 59 lukisan yang baru akan di daftarkan BMN. Koleksi lukisan Museum Istana Kepresidenan Yogyakarta yang berjumlah 494 lukisan terdiri lukisan cat minyak, akrilik, kaca, batik, pastel, dan cat air. Adapun dengan tema lukisan koleksi Museum Istana Kepresidenan Yogyakarta memiliki koleksi lukisan dengan tema antara lain; pemandangan alam, objek (still life), potret, figure manusia, dekoratif, lokalitas, kaligrafi, abstrak, sejarah, dan kebangsaan.

Adapun proses pengumpulan koleksi pada Museum Istana Kepresidenan Yogyakarta menggunakan beberapa cara akuisisi koleksi. Sebagian besar koleksi Istana Negara, khususnya Museum Istana Kepresidenan Yogyakarta berasal dari peninggalan atau warisan para Presiden Indonesia yang menjabat pada saat itu. Koleksi tersebut didapatkan dengan cara pembelian secara pemesanan, maupun pembelian langsung dari sanggar ataupun pameran-pameran, pertukaran dan pemberian dari seniman atau pihak luar (pemimpin negara, tamu kenegaraan, dan masyarakat). Pengoleksian benda-benda seni 
dimulai pada masa pemerintahan Presiden Ir. Sukarno, ia adalah seorang connoisseur dan sekaligus kolektor benda-benda seni yang sejati. Berbagai karya seni yang bermutu dari seniman-seniman ternama Indonesia maupun mancanegara yang menghiasi istana saat ini, merupakan koleksi yang dikumpulkannya ketika menjadi presiden pertama Republik Indonesia sejak kemerdekaan 1945 hingga 1966.

\section{Pengelolaan Koleksi Lukisan Pendataan Koleksi}

\section{Registrasi}

Kegiatan registrasi benda seni koleksi Museum Istana Kepresidenan Yogyakarta yang dilakukan pengelola, ketika suatu benda telah diputuskan menjadi koleksi, pencatatan tersebut meliputi dokumendokumen yang terkait dalam koleksi.

2. Inventarisasi

Inventarisasi koleksi dilakukan pengelola untuk mencatat benda koleksi Museum Istana Kepresidenan Yogyakarta ke dalam buku inventaris koleksi.

3. Katalogisasi

Katalogisasi juga termasuk dalam kegiatan inventarisasi koleksi, yaitu sama-sama mencatat dan mendokumentasikan yang memuat data-data tentang koleksi. Media yang merekam baik secara visual maupun verbal. Adapun jenisnya mempunyai dua macam; Pertama, katalog inventaris hanya untuk pengelola, yang bertujuan membantu pendataan dan pengontrolan koleksi. Kedua, Katalog pameran/istana untuk pengunjung yang bertujuan menjelaskan tentang seluk beluk Istana dan koleksi museumnya.

\section{Penyajian Koleksi}

1. Tahap Pra Karsa

Tahap pra karsa adalah tahap dimana pengelola dan kurator memutuskan hal-hal pokok mengenai rencana penyajian koleksi museum. Adapun penyajiannya menggunakan dua jenis pameran; Pertama, pameran tetap/permanen yang berada di Ruang Museum Istana Kepresidenan Yogyakarta, tipe pameran ini penyajiannya terkonsep dengan matang dan terstruktur.
Kedua, pameran temporer/insidental untuk koleksi-koleksi yang tersebar di dindingdinding Istana, tipe ini biasanya dengan cara merotasi atau rolling lukisan yang dipajang.

2. Tahap Perancangan Konsep

a. Tema dan Proses Kurasi Koleksi

Tema dan pengkurasian koleksi lukisan melibatkan pihak luar istana, yaitu dengan bekerjasama dengan tenaga ahli kurasi karya lukisan, memdalami pengetahuan tentang karya seni dan sejarah seni koleksi Museum Istana Kepresidenan Yogyakarta. Tema kurasinya secara keseluruhan mengangkat tentang ke-Indonesiaan yang berjudul "Semangat Nasionalisme", yang dibagi dalam sub tema dalam ruang-ruang pamer museum, sub tema tersebut antara lain; tentang Presiden, Perjuangan, Yogyakarta, Keanekaragaman Alam dan Keberagaman Budaya Indonesia.

b. Alur Cerita (Story-line)

Alur cerita di Museum Istana Kepresidenan Yogyakarta adalah komponen dokumen yang disajikan dalam pameran, memuat nilai-nilai edukasi yang dibuat oleh kurator, mengikuti garis besar kerangka pameran dan daftar koleksi yang sudah dikurasi. Berikut adalah alur cerita di museum; alur pertama memuat tentang potret dan representasi presiden-presiden Indonesia dari yang pertama hingga yang ke-enam, dilanjutkan dengan potret wakil presiden, kemudian pendamping presiden, lalu tentang jogja dan perjuangan kemerdekaan, yang terakhir tentang kenaeragaman alam, dan keberagaman budaya.

3. Tahap Perancangan Pameran a.Desain dan Layout Ruang Pamer

Dalam hal desain dan penataan ruang pamer, pengelola dan kurator mendiskusikan untuk menyesuaikan koleksi dengan ruang pamer yang akan dipakai. Penataan berdasar pada arus lalu-lintas atau sirkulasi penonton. Museum ini menggunakan metode pendekatan tata letak terstruktur dengan tujuan membatasi 
pengunjung pameran. Pembatasan pengunjung ini merupakan strategi pengelola untuk memudahkan petugas mengawasi pengunjung. Ruang pamer didesain dalam satuarah arus lalu-lintas. Di sisi lain, metode ini mempunyai kelebihan agar pengunjung dapat melihat semua koleksi yang dipamerkan sebelum keluar museum.

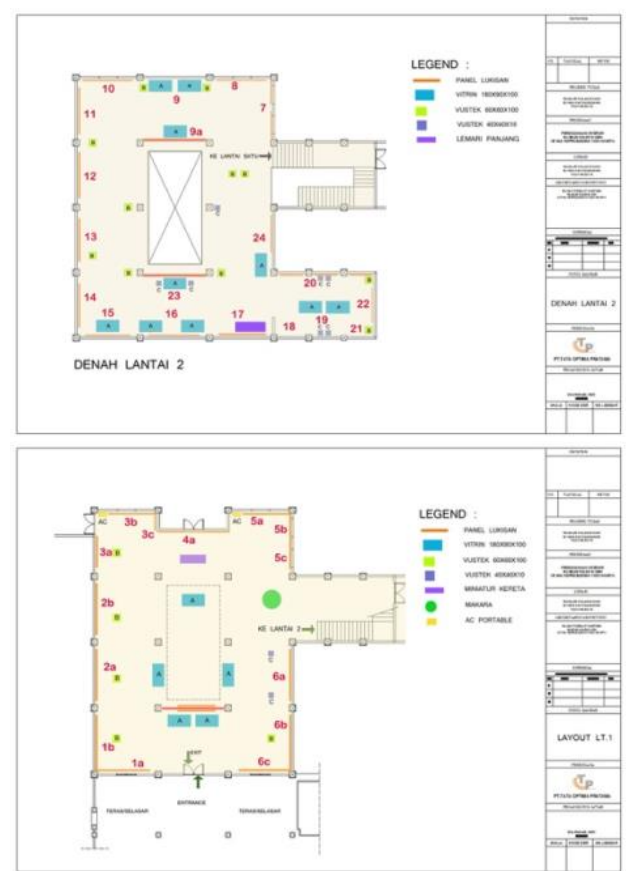

Gambar. B.3.b.3.a Layout Lt. 1 dan 2 Museum Istana Kepresidenan Yogyakarta Dokumen: Mikke Susanto

b. Penataan Koleksi

Penataan koleksi lukisan termasuk dalam kerja kurator, hal ini bertujuan dengan mempertimbangkan komposisi akan membuat nyaman pengunjung. Penataan lukisan koleksi museum diposisikan terpusat pada strata mata pengunjung, untuk ukuran orang dewasa biasanya 1.6 meter. Adapun dalam pengaturan objek lukisan pada garis tengah tingkatan mata, penataan menggunakan beberapa karateristik yang mempengaruhi penempatan, antara lain; Keteraturan, Garis Datar Tengah, Keseimbangan, Mengapit, dan Spiral.

c. Tata Cahaya

Pencahayaan menggunakan jenis pencahayaan elektrik dengan lampu Light Emitting Diode (LED). Tingkat paparan cahaya yang dikeluarkan lampu, dapat diredam oleh adanya kaca akrilik yang dipasang di depan koleksi lukisan, untuk menghindari kerusakan terhadap benda koleksi, yang dapat mempengaruhi warna, pigmen, minyak, kanvas, atau kertas.

d. Teks Pameran dan Labelisasi Koleksi (caption)

Penyampain informasi tidak hanya dilakukan oleh petugas pemandu pameran, tetapi juga dengan media teks pameran dan lebelisasi koleksi. Hal ini membantu pengunjung dalam memahami dan mengapresiasi yang disajikan di museum. terdapat empat elemen teks yang terdapat di Museum Istana Kepresidenan Yogyakarta; teks judul, sub judul, teks pengantar kuratorial, teks grup, dan teks label koleksi.

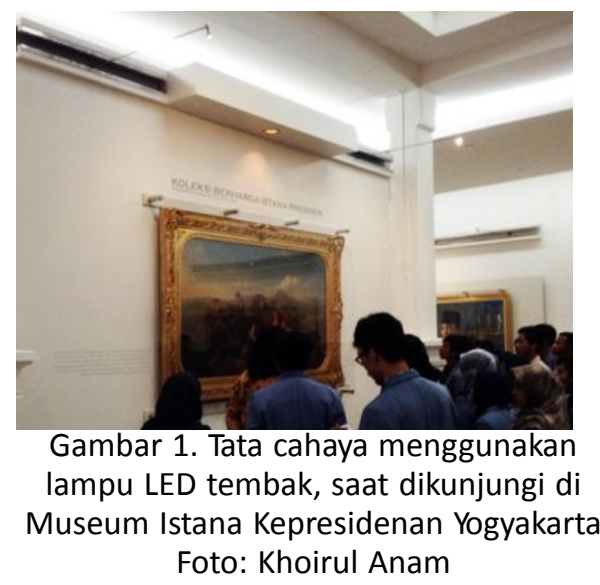

e. Pemandu Pameran

Selain berfungsi untuk memberikan bimbingan, penerangan, petunjuk dan memberikan informasi seputar Istana dan Museum Istana, pemandu juga berfungsi sebagai pengawas dan penjaga kemanan dari pengunjung yang datang.

4. Tahap Evaluasi

Proses evalusi kerja di Museum Istana Kepresidenan Yogyakarta tidak dilakukan sendiri dalam lingkup pengelolaan museumnya. Dilakukan menyeluruh bersama di bawah kendali Kepala Istana Kepresidenan Yogyakarta. Evalusai yang dilakukan pengelola 
museum sebatas pada pengelolaan koleksi, tetapi tidak pada target pengunjung, proses pameran, dan keefektifan pameran.

\section{Pemeliharaan dan Pengamanan Koleksi}

1. Konservasi

Dalam kegiatan konservasi, pengelola dibantu petugas kebersihan melakukan pengecekan secara rutin setiap hari, pengecekan itu meliputi pencahayaan, suhu ruangan, kebersihan ruangan, kebersihan koleksi, dan indikasi terjadinya kerusakan pada koleksi yang berada di ruang pamer maupun di gudang penyimpanan. Seteah dilakukan pengecekan dan terbukti tidak sesuai standar konservasi, maka pengelola harus cepat tanggap terhadap koleksikoleksi yang kotor, rusak dan teridikasi rusak.

2. Restorasi

Kegiatan restorasi dilakukan dalam kurun waktu satu tahun sekali dengan skala prioritas, dimana yang paling penting masuk daftar pertama untuk direstorasi. Skala prioritas ini dilihat dari nilai aset lukisan tersebut. Ketika nilai tersebut lebih murah dari pada biaya restorasi, maka yang dilakukan hanya konservasi preventif atau perawatan ringan saja, seperti kegiatan yang dilakukan pada bab sebelumnya. Kegiatan restorasi tidak dapat dilakukan oleh pengelola museum sendiri, tetapi bekerjasama dengan tenaga ahli yang memiliki keahlian khusus dibidang restorasi. Tim restorasi dipilih secara selektif oleh pengelola museum.

3. Reproduksi

Kegiatan Reproduksi sampai sejauh ini belum pernah dilakukan pengelola. Kasusnya reproduksi dilakukan pihak luar dengan meminta izin dari istana melalui Menteri kemudian turun ke Deputi, lalu ke Kepala Biro, selanjutnya ke Kepala Istana.

4. Pengepakan Koleksi (Packing)

Kegiatan pangepakan koleksi yang dilakukan pengelola menggunakan dua cara yang disesuaikan dengan tujuan pengepakan. Pertama, yang bertujuan untuk dikirim, pengepakanya lebih dipastikan keamananya terhadap guncangan saat proses pengiriman, yaitu menggunakan peti kayu yang di dalamnya menggunakan material palstik bergelembung (bubble wrap) sebagai bungkusnya, namun sebelumnya dilapisi sejenis kain busa (foam polyethylene) untuk menahan gerakan dan goresan terhadap koleksi lukisan. Selanjutnya dilengkapi dengan identitas karya (lebel karya) berupa foto karya, judul, ukuran, dan media. Kedua, yang bertujuan untuk disimpan di dalam gudang penyimpanan, hampir sama dengan pengepakan yang pertama, hanya saja tidak memakai peti kayu dan diberi Silica Gel yang berfungsi menyerap kelembapan dan cairan partikel, dari ruang yang berudara/bersuhu.

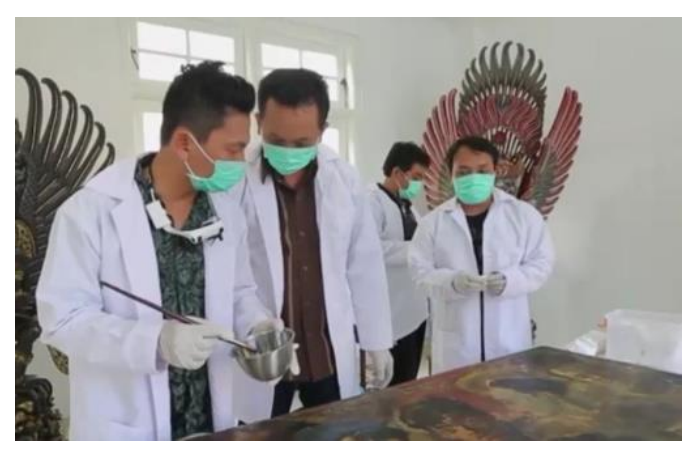

Gambar 2. Kegiatan restorasi yang dilakukan Restorator (tenaga ahli) dibantu pengelola museum, bertempat di Ruang Restorasi. Foto: Istana Kepresidenan Yogyakarta

\section{Pengamanan Koleksi (Security)}

Keamanan lukisan koleksi tergolong baik. Semua itu karena museum masuk dalam satu kompleks dengan tempat tinggal Presiden Republik Indonesia (RI) yaitu Istana Kepresidenan Yogyakarta. Otomastis keamanan koleksi terjamin dengan adanya 4 titik pengamanan. Adapun pengamanan dilakukan oleh Detasemen Polisi Militer (Denpom), Bataliyon Kavaleri 2/TC, Petugas Ketertiban Dan Keamanan Dalam Sekretariat Presiden (Tipkamdal Setpres). Adapun untuk keamanan lukisan secara fisik menggunakan mika akrilik untuk melindungi dari pengunjung yang berniat memfoto dan memalsukan lukisan koleksi Museum Istana Kepresidenan Yogyakarta.

\section{Ruang Penyimpanan (storage)}


Gudang penyimpanan dilengkapi dengan standar keamanan seperti rak besi, perarel berkunci, suhu 18-21, pencahayaan yang cukup, keamanan anti kebakaran, kamera cctv, anti bocor, jeruji-jeruji, selebihnya menggunakan keamanan istana.

7. Asuransi

Upaya pengamanan belum sampai pada tahap asuransi. Entah itu asuransi koleksi museum dan/atau bagunan museum. Pihak pengelola hanya melakukan kegiatan asuransi untuk karya yang dipinjam keluar dari Istana Kepresidenan Yogyakarta. Seperti pada saat pameran "Goresan Juang Kemerdekaan 17:71" pada 2016 dan "Senandung Ibu Pertiwi" 2017 di Galeri Nasional Indonesia Jakarta.

8. Pengurangan Koleksi

Kegiatan pengurangan koleksi dilakukan dengan tiga cara. Pertama, dibuang begitu saja. Kedua, dengan cara dijual di tempat pelelangan. Ketiga, dengan menghadiahkan ke museum lain atau Institusi lain. Kegiatan pengurangan melalui penghapusan belum pernah terjadi pada koleksi lukisan sampai saat ini. Biasanya untuk benda seni yang mengalami kerusakan, tidak dapat diperbaiki, dan tidak mempunyai nilai aset yang tinggi, harus diusulkan melalui Barang Milik Negara (BMN). Adapun penghapusan data di BMN, prosesnya berawal dari usulan pengelola museum. Jika benda koleksi tersebut masih layak untuk dijual, dilakukan kegiatan pengurangan koleksi dengan cara dijual di balai pelelangan.

\section{Kesimpulan}

Berdasarkan penelitian yang telah dilakukan di Museum Istana Kepresidenan Yogyakarta tentang pengelolaan koleksi lukisan, dapat disimpulkan dalam beberapa hal:

1. Struktur organisasi pengelolaan di museum berada dalam taraf baik, dilihat dari hasil pengelolaan koleksi yang baik, dari segi penyajian, pemeliharaan dan pengamanan. Di sisi lain dalam struktur organisasi museum tidak memiliki keorganisasian seperti organisasi museum yang lain, seperti memiliki kepala museum dan jajarannya. Museum hanya memiliki pengelola, hal ini menyebabkan kurang maksimalnya pengelolaan koleksi museum.

2. Koleksi lukisan di museum memiliki enam jenis lukisan, yang memiliki perawatan berbeda-beda, antara lain; lukisan cat minyak, cat air, cat akrilik, kaca, batik, dan pastel.

3. Pengadaan koleksi lukisan di museum paling banyak didapatkan melalui pembelian dan pemberian langsung dari seniman.

4. Pengelolaan data koleksi lukisan di museum yang meliputi registrasi, inventarisasi, dan katalogisasi berada dalam taraf baik dan lengkap, dilihat dari data yang mudah untuk diakses dan tidak membingungkan.

5. Pengelolaan koleksi dengan penyajian lukisan di museum lebih mengarah pada pameran tetap/permanen, karena sudah terkonsep dengan matang. Sedangkan di kompleks Istana yaitu di luar museum, penyajiannya mengarah pada pameran temporer/insidental, karena dapat berubah sewaktu-waktu, untuk dilakukan rolling/pergantian. Hal tersebut mengindikasikan bahwa penyajian dalam taraf sangat baik.

6. Pemeliharan dan pengamanan lukisan koleksi museum berada dalam taraf baik, dilihat dari kegiatan konservasi, restorasi, pengepakan, dan pengamanan yang baik. Adapun dalam hal pengendalian risiko secara finansial yang dilakukan dengan cara mengalihkan risiko dengan menggunakan asuransi, belum dilakukan pihak pengelola terhadap koleksi dan bangunan museum.

\section{Daftar Pustaka}

Azwar, S. (2005). Metode Penelitian. Yogyakarta: Pustaka Pelajar.

Barahmus. (2017). Badan Musyawarah Musea D.I (Daerah Istimewa) Yogyakarta. Retrieved from http://barahmus.museumjogja.org/id/lin $\mathrm{k}$.

Burhan, M. A. (2013). Seni Lukis Indonesia; Masa Jepang Sampai LEKRA,. Surakarta.: UNS Press.

Kemendikbud.go.id. (2017). Museum Balai Kirti. Retrieved from http://kebudayaan.kemdikbud.go.id/mus pres 
Moeloeng, L. J. (2007). Metodologi Penelitian Kualitatif. Bandung: Rosdakarya.

S. Suryabrata. (1998). Metodologi Penelitian. Yogyakarta: Radja Grafindo.

Setiyono, B. (2017). Kembali ke Jakarta. Retrieved from url: https://historia.id/kota/articles/kembalike-jakarta-P4mm6

Susanto, M. (2011). Diksi Rupa. Yogyakarta: DiktiArt Lab \& Djagad Art House.

Susanto, M. (2014). Bung Karno; Kolektor dan Patron Seni Rupa Indonesia. Yogyakarta: Dicti Art Lab. 